\title{
Effective location of shear wall on performance of building frame subjected to earthquake load
}

\author{
Mr.K.LovaRaju', Dr.K.V.G.D.Balaji ${ }^{2}$ \\ Assistant Professor, Department of Civil Engineering, Anil Neerukona Institute of Technology and Sciences, \\ Visakhapatnam, Andhra Pradesh, India ${ }^{1}$ \\ Professor, Dept., of Civil Engineering, GITAM University, Visakhapatnam, Andhra Pradesh, India ${ }^{2}$
}

\begin{abstract}
This paper deals with the non-linear analysis of frame for various positions of shear wall in a building frame. In this present study, the focus is to identify effective location of shear wall in multi-storey building. Considering model one is bare frame structural system and other three models are dual type structural system. An earthquake load is applied to a building of eight storey is located in zone II, zone III, zone IV and zone V as per Code Provision IS18932002. The analysis has been carried out using ETABS software. Pushover curves have been developed and compared for various models. It has been observed that structure with shear wall at appropriate location is more significant in case of displacement and base shear.
\end{abstract}

Keywords: ETABS v 9.7.2, Pushover Analysis, Location of shear wall.

\section{INTRODUCTION}

Shear wall is one of the excellent means of providing earthquake resistance to multi-storeyed reinforced concrete building. Behavior of structure during earthquake motion depends on distribution of weight, stiffness and strength in both horizontal and vertical planes of building. To reduce the effect of earthquake reinforced concrete shear walls are used in the building. These can be used for improving seismic response of buildings. Structural design of buildings for seismic loading is primarily concerned with structural safety during major Earthquakes, in tall buildings, it is very important to ensure lateral stiffness to resist lateral load. The provision of shear wall in building to achieve rigidity has been found effective and economical. Shear walls are usually used in tall building to avoid collapse of buildings. When shear wall are situated in advantageous positions, they can form an efficient lateral force resisting system.

The major criteria now-a-days in designing RCC structures in seismic zones is control of lateral displacement resulting from lateral forces. The effort has been made for investigate the effective location of shear wall for lateral displacement and Base Shear in RCC Frames. For this study four types of structures, with G+7 are considered which one of the frame without shear wall and other three with shear wall in various position.

Non-linear static analysis (pushover analysis) was carried out four types of frames and the frames were compared with the push over curves. Displacement and Base shear is calculated from the curves and compared. The nonlinear analysis of a frame has become an important tool for the study of the concrete behavior including its load-deflection pattern and cracks pattern. It helps in the study of various characteristics of concrete member under different load conditions.

\section{LITERATURE BACKGROUND}

The Applied Technology Council (ATC) is a non-profit, tax exempt corporation established in 1971 through the efforts of the Structural Engineers Association of California. ATC is guided by a Board of Directors consisting of representatives appointed by the American Society of Civil Engineers, the Structural Engineers Association of California. The purpose of ATC is to assist the design practitioner in structural engineering in the task of keeping abreast of and effectively using technological developments (ATC-40) ${ }^{1}$. The preparation of this prestandard was originally undertaken with two principle and complimentary objectives. The first was to encourage the wider application of the NEHRP Guidelines for the Seismic Rehabilitation of Buildings, FEMA 273, by converting it into mandatory language. Design professionals and building officials thus would have at their disposal a more resistant to earthquake. This volume fully meets this first objective. The second objective was to provide a basis for a nationally recognized, ANSIapproved standard that would further help in disseminating and incorporating the approaches and technology of the prestandard into the mainstream of the design and construction practices in the United States (FEMA 356) ${ }^{2}$. A study was conducted on various symmetric and asymmetric structures constructed on plain as well as sloping grounds subjected to various kinds of loads and Structures constructed on plane ground and inclined ground of $30^{\circ}$ slope is considered. Various structures are considered in plan symmetry and also asymmetry with difference in bay sizes in mutual directions (K.V.G.D Balaji et.al; 2012) $)^{3}$. Nonlinear static analysis is an iterative procedure so it is difficult to solve by manual calculation and that's why software is required to do nonlinear static analysis. ETABS 9.7 has features to perform nonlinear static analysis. This is an approach to do nonlinear static analysis in simple and effective manner. (Mrugesh D. Shah et.al; 2011) ${ }^{4}$. An attempt is made to study the 
difference in structural behavior of 10 storey basic moment resisting $\mathrm{RC}$ frames when provided with two different types of shear wall as LLRS (Lateral Loading Resistant System). RC frame with the same columns sizes and orientation as in bare frame with internal shear walls and external shear wall of two different thicknesses are considered (S. V. Venkatesh et.al; 2011) ${ }^{5}$. A study was conducted on symmetric rectangular high-rise structure to find the appropriate location for the shear wall based on its elastic and elasto-plastic behaviour and found that the top deflection was reduced and reached within the permissible deflection after providing the shear wall (Anshuman et.al;2011) ${ }^{6}$.

\section{MODELING AND ANALYSIS OF STRUCTURE}

A residential building of G+7 (8 Story) structure having base dimension of plan $17.8 \mathrm{~m} \times 10 \mathrm{~m}$ with typical floor height $3 \mathrm{~m}$ is considered for the analysis. These buildings were designed in compliance to the Indian Code of Practice for Seismic Resistant Design of Buildings. The building is assumed to be fixed at the base. The sections of structural elements are square and rectangular and Storey heights of buildings are assumed to be constant including the ground storey. Dimensions of shear walls are same in all models. Height of shear wall is as height of building. The buildings are modeled using ETABS Nonlinear $\mathrm{v}$ 9.7.2 software and four different models were studied with different location of shear wall in building frame. Models are studied in all four seismic zones comparing lateral displacement and Pushover curve.

\subsection{The plan of the building model is given below:}

Model 1 - Floor plan of the bare framed structure.

Model 2- Floor plan of the dual system as shear wall in Location-1.

Model 3 - Floor plan of the dual system as shear wall in Location-2.

Model 4 - Floor plan of the dual system as shear wall in Location-3.

\begin{tabular}{|c|c|}
\hline Details of Building & $\begin{array}{c}\text { For eight } \\
\text { story }\end{array}$ \\
\hline No. of stories & Eight $(\mathrm{G}+7)$ \\
\hline Floor to Floor Height & $3.0 \mathrm{~m}$ \\
\hline $\begin{array}{c}\text { Beam size longitudinal and transverse } \\
\text { direction }\end{array}$ & $300 \times 450 \mathrm{~mm}^{2}$ \\
\hline Column size & $350 \times 750 \mathrm{~mm}^{2}$ \\
\hline Thickness of slab & $120 \mathrm{~mm}$ \\
\hline Thickness External Wall & $152 \mathrm{~mm}$ \\
\hline Thickness of Internal wall & $102 \mathrm{~mm}$ \\
\hline Grade of Concrete and steel & $\begin{array}{c}\text { M30 and } \\
\text { Fe415 }\end{array}$ \\
\hline
\end{tabular}

Table-1 Preliminary data

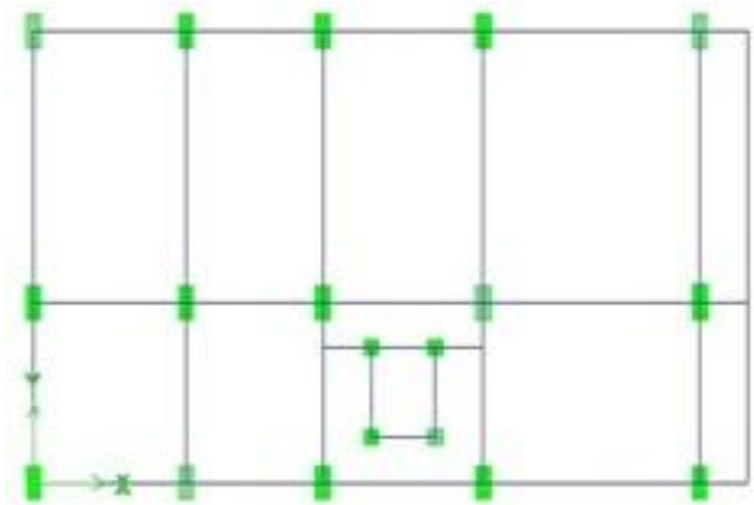

Figure 1: Model-1 Plan without Shear Wall

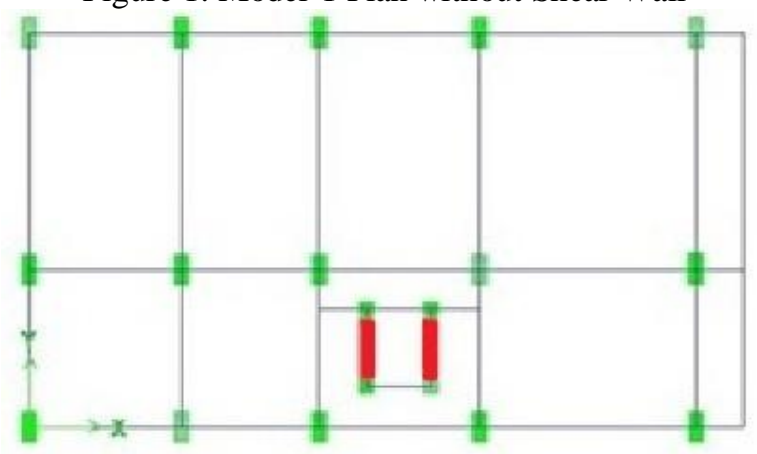

Figure 2: Model-2 Plan with Shear Wall in Location-1

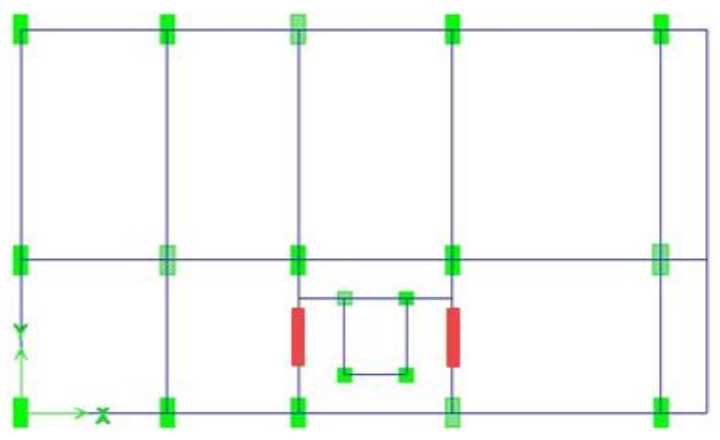

Figure 3: Model-3 Plan with Shear Wall inLocation-2

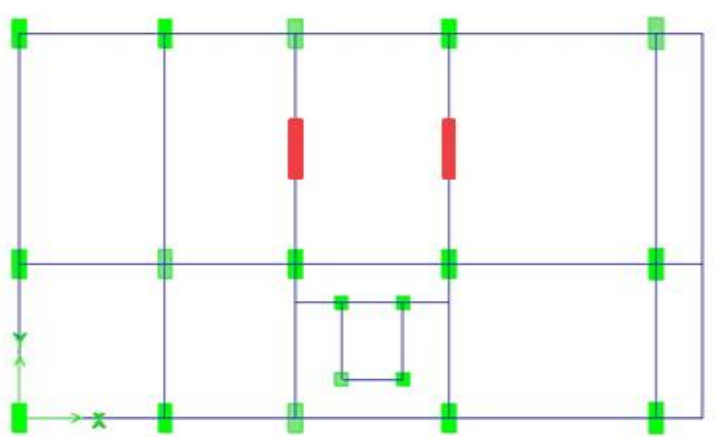

Figure 4: Model-4 Plan with Shear Wall in Location-3

\section{RESULT AND DISCUSSION}

The seismic analysis of the frame models that includes different location of shear walls has been done using software ETABS and the results are shown below. The parameters which are studied are lateral displacement and base shear. 


\subsection{Linear Static Analysis:}

Linear analysis of all the considered structures is carried out using ETABS software. The general loads are considered for all the buildings and Four different cases are considered in the study.

\subsubsection{Lateral Displacement:}

Lateral displacement for all model in all four seismic zones are as shown in fig.

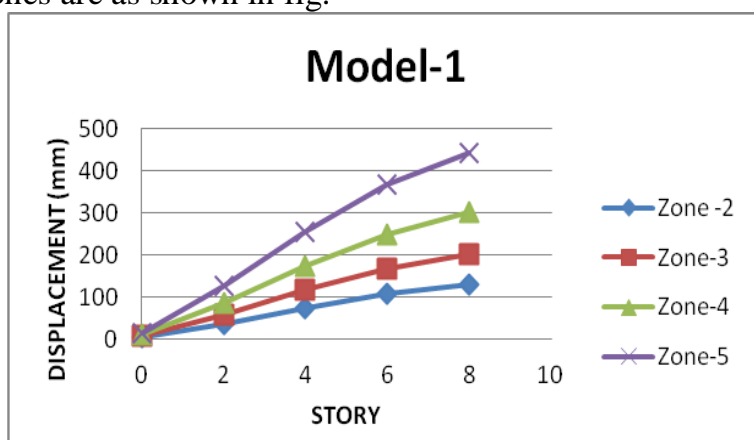

Figure 5a: Lateral Displacement for without Shear Wall in all four Seismic Zones Model-1

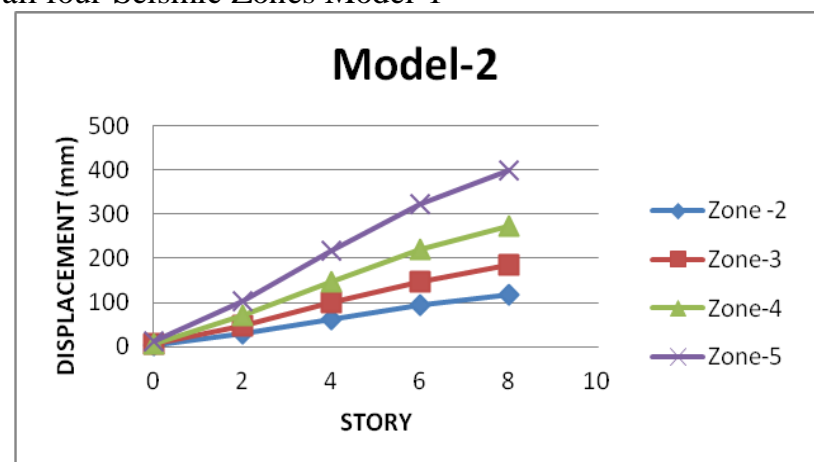

Figure 5b: Lateral Displacement for frame with Shear Wall at Location-1 in all four Seismic Zones Model-2

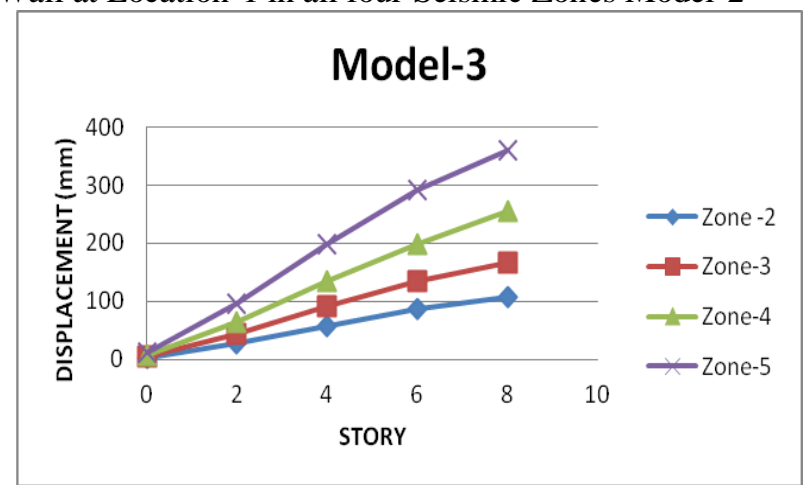

Figure 5c: Lateral Displacement for frame with Shear Wall at Location-2 in all four Seismic Zones Model-3

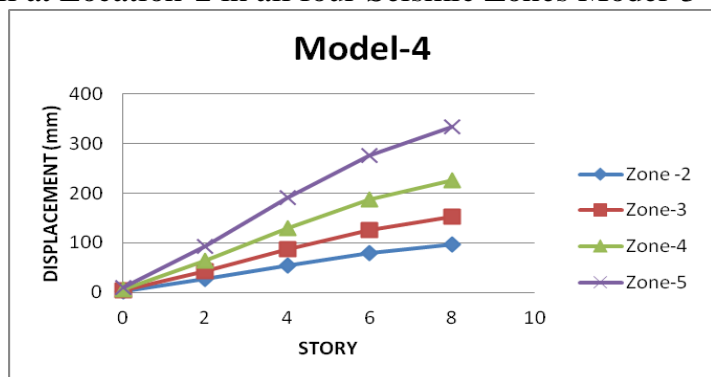

Figure 5d: Lateral Displacement for frame with Shear Wall at Location-3 in all four Seismic Zones Model-4
From figure $5 \mathrm{~b}$ it observed that maximum displacement of all models in zone II, III, IV, V as comparing model-2 from model-1 its reduced displacement as $8.5 \%$ in Zone-2, 9.1\% in Zone-3, 9.5\% in Zone-4, 9.7\% in Zone-5.

From figure $5 \mathrm{c}$ it observed that maximum displacement of all models in zone II, III, IV, V as comparing model-3 from model-1 its reduced displacement as $17.5 \%$ in Zone$2,18.1 \%$ in Zone-3, $15.5 \%$ in Zone-4, $18.6 \%$ in Zone-5.

From figure 5d it observed that maximum displacement of all models in zone II, III, IV, V as comparing model-4 from model-1 its reduced displacement as $25.8 \%$ in Zone$2,25.2 \%$ in Zone-3, 24.8\% in Zone-4, 24.4\% so it can concluded as shear wall in location-3 (Model -4) is more effective than the other models and effectiveness of shear wall is observed.

\subsection{Non-Linear Static Analysis of Structure:}

Pushover analysis is a static nonlinear procedure in which the magnitude of the lateral loads is incrementally increased, maintaining a predefined distribution pattern along the height of the building. Pushover analysis can determine the behavior of a building, including the ultimate load and the maximum inelastic deflection. Nonlinear effects are modeled and the structure is pushed until a collapse mechanism is developed. At each step, the base shear and the roof displacement can be plotted to generate the pushover curve.

\subsubsection{Necessity of Non-Linear Static Pushover Analysis (NLSA):}

The existing building can become seismically deficient since seismic design code requirements are constantly upgraded and advancement in engineering knowledge. Further, Indian buildings built over past two decades are seismically deficient because of lack of awareness regarding seismic behavior of structures. The wide spread damage especially to RC buildings during earth quakes exposed the construction practices being adopted around the world, and generated a great demand for seismic evaluation and retrofitting of existing building stocks.

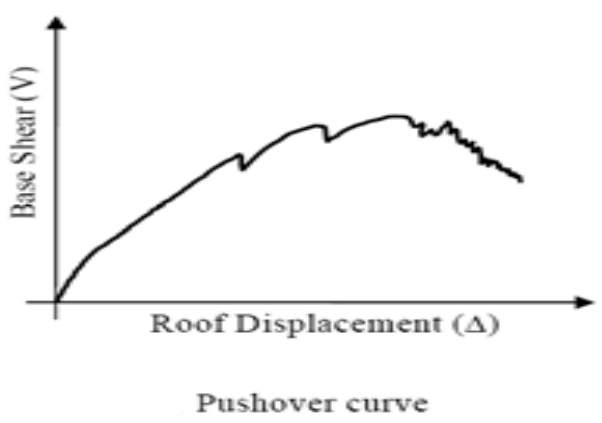

Figure 6: Shows the Pushover curve 


\subsubsection{Purpose of Push-over Analysis:}

The purpose of pushover analysis is to evaluate the expected performance of structural systems by estimating performance of a structural system by estimating its strength and deformation demands. Resultant base sheardisplacement curve has been obtained for structure, which shows behavior of structure with respect to base shear. Pushover or nonlinear static analysis is carried out for all the cases considered and finally pushover curves are obtained.

\begin{tabular}{|c|c|c|}
\hline TYPE & $\begin{array}{c}\text { DISPLACEMENT } \\
\text { (mm) }\end{array}$ & $\begin{array}{c}\text { BASE } \\
\text { FORCE } \\
(\mathrm{KN})\end{array}$ \\
\hline $\begin{array}{c}\text { RCC frame without } \\
\text { shear wall (model- } \\
\text { 1) }\end{array}$ & $329 \mathrm{~mm}$ & 1790 \\
\hline $\begin{array}{c}\text { RCC frame with } \\
\text { shear wall location- } \\
\text { 1 (model-2) }\end{array}$ & $251 \mathrm{~mm}$ & 1935 \\
\hline $\begin{array}{c}\text { RCC frame with } \\
\text { shear wall location- } \\
2 \text { (model-3) }\end{array}$ & $245 \mathrm{~mm}$ & 1942 \\
\hline $\begin{array}{c}\text { RCC frame with } \\
\text { shear wall location- } \\
3 \text { (model-4) }\end{array}$ & $241 \mathrm{~mm}$ & 1985 \\
\hline
\end{tabular}

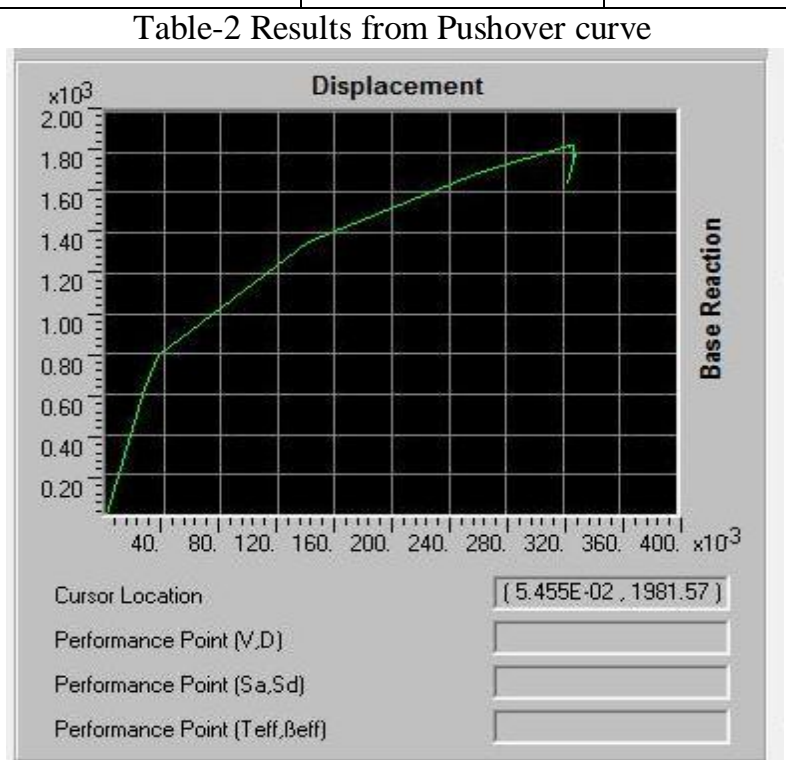

Figure-7: Shows Pushover Curve of model using Etabs Software

From Table-2 it can be observed that from static nonlinear analysis the maximum displacement for frame in model-1 observed from Pushover curve is $329 \mathrm{~mm}$ and the corresponding base reaction is $1790 \mathrm{KN}$.

From Table-2 the push-over curve, it is noted that the maximum displacement for frame in model-2 observed from Pushover curve is $251 \mathrm{~mm}$ and reduction upto $24 \%$ in displacement when the shear wall is provided at location-1 and the corresponding base reaction is $1935 \mathrm{KN}$.
From Table-2 the push-over curve, it is noted that the maximum displacement for frame in model-3 observed from Pushover curve is $245 \mathrm{~mm}$ and reduction upto $25.5 \%$ in displacement when the shear wall is provided at Location-2 and the corresponding base reaction is $1945 \mathrm{KN}$. From Table-2 the push-over curve, it is noted that the maximum displacement for frame in model-4 observed from Pushover curve is $241 \mathrm{~mm}$ and reduction upto $26.7 \%$ in displacement when the shear wall is provided at Location-3 and the corresponding base reaction is $1985 \mathrm{KN}$. From the pushover curves Table-2 shows the results, indicating that RCC frame (Model-2) with shear wall are able to resist about $7.49 \%$ more base-shear than that of normal RCC frame.

From the pushover curves Table-2 shows the results, indicating that RCC frame (Model-3) with shear wall are able to resist about $7.82 \%$ more base-shear than that of normal RCC frame.

From the pushover curves Table-2 shows the results, indicating that RCC frame (Model-4) with shear wall are able to resist about $9.82 \%$ more base-shear than that of normal RCC frame.

\section{CONCLUSIONS}

In the present study four models of eight-storey structure is considered, which one of model is bare frame and other models with shear wall location in position-1,position2,position-3 in all seismic zones and corresponding baseshear and lateral displacement derive from the pushover curve using Etabs software. Provision of a shear wall influences the seismic performance of the structure with reference to strength and lateral displacement. Shear wall in position-3 performs better and the base shear increased by $9.82 \%$ when compared to the frame without shear wall. Shear wall in position-3 performs better with reference to lateral displacement and it reduces by $26.7 \%$ when compared to the frame without shear wall. The provision of shear wall position in an appropriate location is advantageous and the structure performs better for an existing or a new structure.

\section{REFERENCES}

1. ATC. Seismic Evaluation and Retrofit of Concrete BuildingsVolume 1 (ATC-40). Report No. SSC 96-01. Redwood City (CA): Applied Technology Council; 1996.

2. FEMA 356 NEHRP PreStandard and Commentary for the Seismic Rehabilitation of Buildings. (2000).

3. K.V.G.D Balaji, N.Jitendra Babu \& S.S.S.V Gopalaraju "Pushover Analysis of Unsymmetrical Framed Structures on Sloping Ground". International Journal of Civil, Structural Environmental and Infrastructure Engineering, Research and Development (IJCSEIERD), ISSN 2249-6866,Vol. 2 Issue 4 Dec - 2012.

4. Mrugesh D. Shah, Sumant B. Patel "Nonlinear Static Analysis of R.C.C. Frames (Software Implementation ETABS 9.7)" National Conference on Recent Trends in Engineering \& Technology.

5. S. V. Venkatesh, H. Sharada Bai, "Effect of Internal \& External Shear Wall on Performance of Building Frame Subjected To Lateral Load" International Journal of Earth Sciences and Engineering, ISSN 0974-5904, Volume 04, No 06 SPL, October 2011. Anshuman. S, Dipendu Bhunia, Bhavin Ramjiyani,"Solution of shear wall location in multistory building", International journal of civil and structural engineering, 2011. 